\title{
Message for periodontal health promotion by host activation through gingival stimulation of toothpick method
}

Tatsuo Watanabe

Emeritus Professor, Okayama University Dental School, Japan

As you know, there is no difference between the Bass method and the scrubbing method, the purposes of these methods are removal of dental plaque and then expect natural healing of wound. In contrast, the toothpick method proliferates gingival cells, actively improves the host's resistance, and prevents and treats periodontal disease and peri-implantitis. The toothpick method targets a different part on gingiva from removal of dental plaque of the others. Therefore, the toothpick method can significantly improve gingival bleeding in one week compared to other methods.

Periodontal pathogens (especially the red complex) use blood as an essential nutrient, so they can no longer grow without gingival bleeding. And then inflammatory symptoms in gingiva disappears, and recurrence is suppressed. No gingival bleeding means that the ulcer in the periodontal pocket has been cured, and that an epithelial barrier prevents recurrence of the infection.

The periodontal pocket ulcerations accept periodontal pathogens to enter the periodontal tissue. These pathogens are phagocytosed by neutrophils and sterilized with active oxygen and nitric oxide. The phagocytosing neutrophils also thaw within 4-5 days, and release endotoxins. Endotoxin is thought to spread throughout the body via the blood and exacerbate chronic degenerative diseases. In fact, patients with cured gingival bleeding have encountered cases in which HbAlc has decreased from 9.2 to 6.8 in a half year, and another case in which HbAlc has gradually decreased to 6.9, 6.8, and 6.7. From the above, we can see the significance of stopping gingival bleeding.

The toothpick method is the most effective for stopping gingival bleeding, but there are two important things. One is the duration and force of brushing, and the other is that the cells grow is limited where the bristles hit. If you brush once a day with a manual toothbrush, the best brushing time is 20 seconds per place (equivalent to 36 minutes for all jaws). In the clinic, we only brush for 3-4 seconds (equivalent to 6-7 minutes for the whole jaw). Gingival bleeding is still clearly improved, but not the best. By the way, the brushing force with 2 rows and 6 hair bundles, a medium toothbrush (She Love $2 \times 6$ ), the cell proliferation can be seen most at $200 \mathrm{~g}$ weight.

The other is that the cells proliferate in limited area only where the brush tips hit. The initial onset of gingivitis is in the interdental region. The most progressive part of periodontitis is the interdental area. That is why the toothpick method is recommended, which allows the toothbrush tips to reach the interdental area.

In the actual clinic, I immediately brush the patient gum by toothpick method and then finally brush again with toothpaste. The index of performance should be the number of teeth with gingival bleeding at professional tooth-brushing. Using this index, most patients have significantly improved in gingival bleeding at the second visit compared to the first visit. Bleeding during brushing is more sensitive than BOP, and the goal is no bleeding at brushing.

For patients with severe periodontitis, difficulties to cure in gingival bleeding, and patients with peri-implantitis, I add the specially designed electric toothbrush, TAPG brushing after the first brushing. Only one time use of TAPG has been quite effective one month later, and the same data has been shown by Dr. Shimono of Okayama University Preventive Dentistry. This is surprising from 
common sense.

In addition, a summary of the "Toothpick Method" and the results of the TAPG questionnaire in Japanese will be enclosed. I hope you find it helpful.

I will come to see you a Fukuoka on 24-26th, April, if I am free.

With best wishes,

Tatsuo Watanabe

Minato 451-172, Naka-ku, Okayama 703-8266, Japan (Office HAT Inc. Haga 5303 ORIC 321, Kita-ku, Okayama 701-1221, Japan) Tel: +81-86-230-6830 Fax: +81-86-230-6831 E-mail: wyobou1@msn.com https://orcid.org/0000-0001-9711-3439

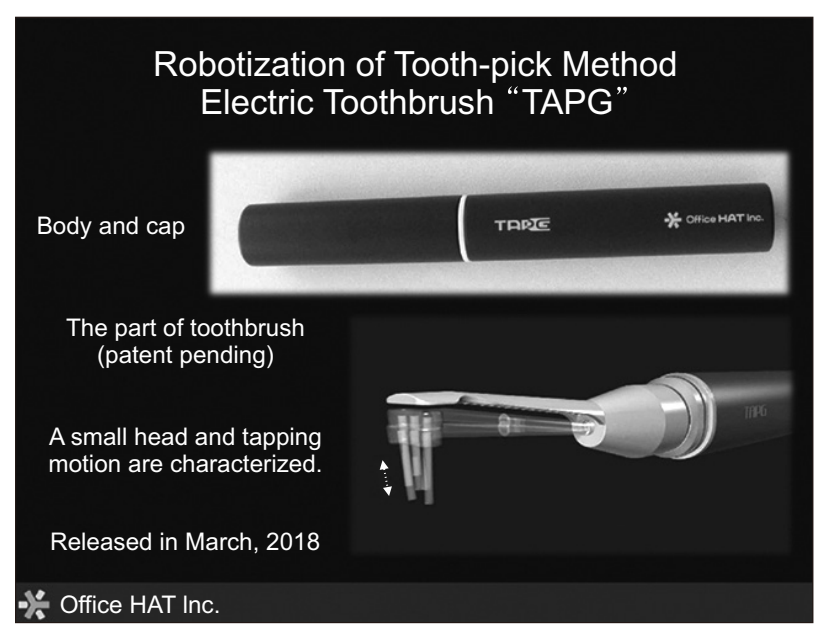




\section{와타나베법 치은자극효과로 유도되는 치주조직의 숙주활성화요법}

와타나베 타츠오

일본 오카야마대학 치학부 명예교수

여러분들이 모두 아시다시피 잇솔질에 있어서 바스법(Bass method)과 횡마법(scrubbing method)는 차이가 별로 없습니다. 이들 방법들의 목적은 치면세균막의 제거이며, 치면세균막을 제거한 다음 자연적인 치유를 기대합니다. 그와 반대로 와타나베 잇솔질법(Watanabe method, toothpick method)의 목적은 치은세포를 증식하고, 적극적으로 숙주의 저항성을 높임으로써 치주질환과 임플란트주위염을 예방하고 치료합니 다. 그만큼 와타나베 잇솔질법(toothpick method)의 목적은 다른 잇솔질 방법에서 추구하는 치면세균막 제거와는 달리 치은에 영향을 주는 것입 니다. 따라서 와타나베 잇솔질법은 1 주일 내에 치은출혈 개선에 있어서 다른 잇솔질법보다 유의하게 효과가 있습니다.

치주병원균(특히 적색 복합체)은 자신이 살아가는 데 있어서 필수 영양소로서 혈액을 사용합니다. 그래서 치주병원균들은 치은출혈이 없이는 더 이상 자랄 수 없습니다. 그리하여 치은의 염증 증상이 사라지면 치주질환 재발은 억제됩니다. 치은출혈이 없다는 것은 치주낭의 궤양이 치료되 었으며, 상피세포 장벽이 치주질환 재발을 방지한다는 것을 의미합니다.

치주낭에 궤양이 생김으로써 치주병원균들이 치주조직 속으로 침투하게 됩니다. 호중구는 포식작용으로 치주병원균을 잡아먹고, 활성산소 와 산화질소로 사멸합니다. 포식작용을 한 호중구는 4-5일 이내에 녹아 터지면서 내독소(endotoxin)를 방출합니다. 내독소는 혈액을 통해 몸 전 체로 퍼지고 만성 퇴행성 질환을 악화하는 것으로 생각되고 있습니다. 실제로, 치은출혈이 치료된 환자에서 6개월 이내에 HbAlc 수치가 9.2에서 6.8로 감소하였고, 다른 사례에서는 $\mathrm{HbAlc}$ 수치가 $6.9,6.8,6.7$ 로 점차 감소하였습니다. 여기에서 우리는 치은출혈을 멈추게 하는 것은 얼마나 큰 의미를 가지는지 알 수 있습니다.

와타나베 잇솔질법은 치은출혈을 멈추게 하는 데에 가장 효과적입니다만, 실행을 하는 데에는 두 가지 중요한 점이 있습니다. 하나는 잇솔질 지속시간과 잇솔질을 할 때 가하는 힘의 크기(force)이고, 다른 하나는 치은세포 증식이 잇솔모가 닿는 곳에서만 국한하여 증식한다는 것입니다. 여러분들이 수동잇솔로 하루에 한 번 잇솔질을 하면, 가장 최적 잇솔질 시간은 잇솔질하는 부위마다 20초로서 상하악 모두 잇솔질 시간은 36 분에 해당됩니다. 진료실에서 환자들의 이를 닦아줄 경우, 우리들은 한 부위당 3-4초, 상하악 모두에서는 6-7분 동안 이를 닦아주게 됩니다. 이 정도로 서도 치은출혈은 상당히 개선이 되겠습니다만 최선은 아닙니다. 한편, 잇솔모 강모가 2줄로서 6개의 묶음으로 심어져 있고, 강모 강도가 중강도 (medium)인 잇솔(She Love $2 \times 6$ )로서 잇솔질을 할 경우, 치은세포 증식은 $200 \mathrm{~g}$ 의 힘으로서 닦을 경우에 가장 많이 일어나고 있습니다.

다른 하나는 잇솔강모가 닿는 제한된 부위에서만 치은세포가 증식한다는 것입니다. 일반적으로 치은염이 처음 일어나는 곳은 치간부위입니 다. 치주염의 진행에서 가장 중요한 부분은 치간부위라는 사실이 와타나베 잇솔질법(toothpick method)이 권장되는 이유입니다. 와타나베 잇솔 질법으로 이를 닦을 경우에 잇솔 강모 끝이 치간 사이에 닿을 수 있습니다.

실제 진료실에서는 본인은 와타나베법(toothpick method)으로 환자의 잇몸을 닦은 후에 다시 세치제(치약)으로서 전체적으로 이를 다시 닦 아줍니다. 전문가잇솔질의 효과는 이를 닦을 때 치은에서 출혈이 일어나는 치아의 수에 좌우됩니다. 치은출혈이 되는 치아의 수로서 보면 대부분 의 환자들은 첫 번째 방문과 비교하여 두 번째 방문에서 치은출혈이 크게 개선이 됩니다. 환자에게 잇솔질을 해 줄 때 출혈이 되는 것은 임상검사 로서 측정한 치은출혈지수(BOP: Bleeding On Probing)보다 훨씬 더 민감하므로, 최종 목표는 잇솔질을 할 때 출혈이 되지 않는 것입니다.

중증 치주염 환자와 임플란트주위염 환자에서 치은출혈을 치료하기는 상당히 어렵습니다. 이 경우, 처음 전문가잇솔질을 한 후 다음 방문부 터는 와타나베법 전용 전동잇솔(TAPG)를 부가적으로 같이 사용합니다. 딱 한번 TAPG를 사용하고서도 1개월 후에 크게 효과가 있었습니다. 오카 야마대학 Shimono 박사도 같은 자료를 보고한 바가 있습니다. 이런 결과는 일반적인 상식으로 상상하기 어려울 정도의 놀라운 것입니다.

일본어로 된 와타나베법(toothpick method)의 요약한 것과 와타나베법 전용 전동잇솔(TAPG)을 다음에 덧붙여 보내 드리겠습니다. 이것들 이 여러분들께도 도움이 되기를 바랍니다. 
여유가 생기면 일본구강위생학회가 열리는 4월 24-26일 후쿠오카에 가서 여러분들을 뵙고 싶습니다. 건강하게 지내시기 바랍니다. 와타나베 타츠오 드림.

(우) 703-8266, 일본 오카야마 나카구 미나토 451-172 (Office HAT Inc. Haga 5303 ORIC 321, Kiita-ku, 오카야마 701-1221, Japan) (번역. 부산대학교 치의학전문대학원 예방과사회치의학교실 교수 김진범) 